\title{
Post-Soviet Primas: Challenging Archive and Repertoire
}

\section{Cover Page Footnote}

The author would like to acknowledge Professor Mary Buckley, who reviewed this essay prior to publication; her input was invaluable and has materially strengthened this article. 


\section{Introduction}

Emerging as an independent art form in the eighteenth century, ballet carved out a space within theatre arts for shaping, releasing and advocating for one's emotions and personal experiences. At the same time, over the course of its history, ballet became closely associated with state authority, as state ballet schools and theatres became the primary institutions for ballet training and performance in many nations. Perhaps nowhere has this link between the state and ballet been as pronounced as in Russia, where ballet has occupied a distinguished space of state-sponsored art throughout Russia's Imperial, Soviet and PostSoviet periods. With this distinction as a historically state-supported institution, but at the same time renowned for its leading artists, Post-Soviet ballet represents a unique case study that contests the binary academic framing of ballet in Russia as either an independent art form with its own social, cultural and political messages, or as a fully-dependent medium of state propaganda. Critically, in this generally accepted dualistic theorization of ballet, dance scholars, critics, and choreographers have sometimes overlooked the perspective of the performers. As I show in this work, narratives of leading Post-Soviet female ballet artists offer a unique and fundamentally different understanding of Russian classical ballet and its contested position between archive and repertoire.

I set out to examine narratives of leading Post-Soviet prima ballerinas, developed in their public interviews with journalists, producers, and other cultural actors. ${ }^{12}$ I analyze ballerinas' framing and positioning of two significant elements of dance: choreography and technique. I argue that the artists use the notions of "school," "classicism," and "frames" rather than concepts of technique, and open a unique artistic narrative of viewing ballet as an archival practice. ${ }^{3}$ Secondly, I note that Post-Soviet ballerinas refer to classical ballets as "texts," "editions," or "drawings" to underscore the perceived archival nature of classical ballet, and to locate the concept of choreography outside of the sphere of classical ballet and the geographical space of Russia. ${ }^{4}$ Finally, I show that the artists perform these narratives in the public interviews to critique Post-Soviet balletic classicism and linguistically locate and associate ballet (as a practice) within the sphere of the archive.

Pointing to the specific rift between the archive of texts and repertoire of embodied knowledge, Diana Taylor theorizes dance as a non-archival nonverbal embodied practice. In The Archive and Repertoire: Performing Cultural Memory in the Americas Taylor locates dance within the framework of repertoire: "Nonverbal practices-such as dance, 
ritual, and cooking, to name a few - that long serve to preserve a sense of communal identity and memory, were not considered valid forms of knowledge." 5 While not undermining dance's capacity to transcend embodied memory and knowledge, it is significant to see how ballet artists conceive their own practice and its workings. In the epicenters of the Russian ballet world-Moscow and St. Petersburg-contemporary Russian primas refer to ballets as "texts" or "editions" and to dance technique as a "school" or "klassika [classicism]." "Underscoring the archival nature of classical ballet works and institutional elements of technique, leading ballerinas undermine the very location of dance in repertoire, perpetuated by such works as The Archive and The Repertoire, and theorize dance in their own way.

In the past decade, there has been a resurgent interest to Russian ballet; however, recent works, like Christina Ezrahi's Swans of the Kremlin: Ballet and Power in Soviet Russia and Janice Ross's Like a Bomb Going Off: Leonid Yakobson and Ballet as Resistance in Soviet Russia focus specifically on the Soviet period and its well-known male choreographers. ${ }^{7}$ The newest Simon Morrison's Bolshoi Confidential: Secrets of the Russian Ballet from the Rule of the Tsars to Today attempts to encompass the history of Russian ballet as a state art from its origins and finishes with the Soviet period, discounting the time period since the collapse of the USSR in 1991. Additionally, Morrison's work dedicates only one chapter to prima-inspired choreography, through analysis of the autobiography of Maya Plisetskaya, a Soviet-era prima of Moscow's Bolshoi Theatre. ${ }^{8}$ Furthermore, Morrison examines Plisetskaya's artistic contribution largely through the accounts of two male cultural actors: Mikhail Chulaki, the former director of the Bolshoi Theater, and George Feifer, an American writer and journalist. This focus on the Soviet period and Soviet male choreographers, such as Yurii Grigorovich or Leonid Yakobson, is partially informed by the scholarly intrigue over the previously unavailable Soviet archives, and partially by the gendered structure of Soviet ballet. To date, it is largely accepted that the highest achievement for a female dancer in Russian ballet is the status of a prima-ballerina, with choreography largely remaining the domain of male ballet artists. ${ }^{9}$

In my analysis, I offer a reading of Post-Soviet primas' narratives, developed in the interviews with them and documentary films, from the perspective of a Post-Soviet ballettrained dancer. Specifically, I examine public interviews with Svetlana Zakharova, a former prima of the Mariinsky Ballet (1997-2003) and a current prima with the Bolshoi 
Ballet (2003-present); Ulyana Lopatkina, a former prima of the Mariinsky Ballet (19912017); Diana Vishneva, a current prima of the Mariinsky Ballet (1996-present); and Mariya Aleksandrova, a former prima of the Bolshoi Ballet (1997-2017). I turn to the rich scholarly tradition of looking at the notions of technique and choreography to examine ballerinas' narratives, highlighting the archival nature of Russian ballet. As Kate Elswit argues in "Mapping Movement on the Move: Dance Touring and Digital Methods," bringing together digital humanities and theatre and dance, offers new perspectives of looking at dance and theater, as well as their archives and repertoires. ${ }^{10}$ Through the consideration of primas' narratives, available in the digital archives, this essay attempts to shed light on the ways female ballet dancers theorize ballet works and affect their audiences' perceptions of them. Emphasis on these oral narratives also challenges and undermines feminist scholarship that conceives virtuosity and technical excellence as the only empowering factor in ballerinas' careers and lives.

\section{Russian Classical Ballet Technique: Shkola [School], Klassika [Classicism], and Ramki [Frames]}

In critical dance scholarship, technique might be theorized as a continuum, where the notion varies from technique as disabling and restricting the dancer to technique as a liberating force, offering new possibilities for dancers. Recent works by Susan Foster, Randy Martin, Judith Hamera, and Claudia Brazalle define a spectrum of various definitions and understandings of technique relative to the concept of the body. According to Susan Foster, technique is a set of procedures, reforming the perceived body towards ideal. ${ }^{11}$ For Randy Martin, while there is a common notion of mastering technique in the sphere of dance, in fact, it is technique that masters the body. ${ }^{12}$ Judith Hamera furthers Martin's and Foster's assumptions about the primary relevance of verbal expressions in technique transmission to argue that technique, in fact, functions as a language. ${ }^{13}$ Finally, according to Brazalle, the very philosophy and experience of bodily extension in space and exceeding perceived limits often translates into extending one's mobility in social and geographical spaces. ${ }^{14}$

In her work "Dancing Bodies," Susan Foster defines dance technique as a connection between "perceived body" and the "ideal" - the perfect or impossible body. According to Foster, "Each technique cultivates bodily strength, flexibility, and alignment, the shapes made by the body, the rhythm of its movement, and the quality and amount of 
tension throughout it." ${ }^{15}$ Importantly, Foster argues that technique realizes itself through constant repetition and "training regime"; associating dance technique with regiment-a term, highly saturated with political meanings - points toward the notions of repression, domination, discipline, and regularity. In "Between Technique and The State: The Univers(ity) in Dance," Randy Martin theorizes technique as a product of authority that develops a connection between dance pedagogy, body, and national identity. Teaching (through gestural and verbal commands) becomes a method for technique transmission and its organization of bodily movements in dance. Martin states: "teaching is not done by example but with the word, for technique is a vocabulary that carries choreographic will and insists on apparent translatability of what is otherwise untranslatable between different media of expression." 16 Verbal expression, then, according to the author, is a method of technique's transmission and domination of the dancer's body and its movements. In this implied argument, Martin echoes Susan Foster's significance of metaphors. Foster writes: "Metaphors open out into related metaphors, leading the dancer further into a given system for conceptualizing the body. The daily routines of training consolidate metaphoric knowledge and thereby produce bodily habits..."17

In Dancing Communities: Performance, Difference and Connection in the Global City Judith Hamera highlights technique as "a signifier of affiliation" and defines it as a "useful synecdoche for the complex web relations that link performers to particular subjectivities, histories, practices, and to each other." Thus, while not denying oppressive features of technique, Hamera states that technique might have liberating aspects to it, specifically in its language-like function and its potential to connect dancers to various subjectivities and diverse urban spaces. ${ }^{18}$ In "(Un)covering Ground: Dance, Space and Mobility" Brazzale points out that covering the ground in a dance class decodes into covering the ground elsewhere. As Brazzale writes, "exhorting me to expand the kinesphere of my self-conscious female teenage body, dance training enabled me to challenge conventional female modes of moving and living in space, which, as feminist theory pointed out, are traditionally constructed in restrained and inhibited ways." 19 Critically, in her work, Brazzale points to particular processes of training and studying techniques of ballet and modern dance, which offer alternative ways of thinking about the body and bodily mobility and which ultimately lead dancers to pursue mobility not only in dance but life in general. 
Importantly, contemporary Russian primas define two major techniques or "schools"- one affiliated with the Bolshoi Ballet in Moscow and the other with the Vaganova Academy in St. Petersburg. ${ }^{20}$ These schools select, train and recruit artists for, respectively, the Bolshoi Ballet and the Mariinsky Theatre that had historically different systems of state patronage and control of their productions. Although ballerinas present these ballet schools as drastically different, the schools place similar emphasis on transmission of classical historical ballets and technique associated with them. In 2014 documentary film Prima-Balerina Bolshogo Teatra Svetlana Zakharova. Otkrovenie [Bolshoi Ballet's Prima-Ballerina Svetlana Zakharova. Revelation] Svetlana Zakharova stated:

Our Russian school of ballet, of course, is focused on classicism... The correct basics of classical dance are here, in Russia. However, I will state honestly-yes, at the beginning it is truly interesting to learn these classical ballets. I danced about eight to ten various editions of some of them. But, later you just understand that it is impossible to dance them year after year - all the same - so you want to change something. ${ }^{21}$

Here, Zakharova implies that technique or "Russian school of ballet" reproduces itself though re-staging of Russian Imperial ballets, such as The Swan Lake, The Sleeping Beauty, The Nutcracker, Giselle, and Soviet-era ballets, like Cinderella, Spartacus and others. The ballerina's claim about technique, as being focused on "classicism," signifies that dance technique is initially attached to the repertory of classical renditions of Imperial and Soviet ballets. ${ }^{22}$ Even though her response starts with an almost nationalistic glorification of the "Russian school" (or technique), the ballerina transitions to the impossibility of dancing the same ballets "year after year," and the need "to change something," meaning the repertory and performed roles. In that transition from the glorification of technique to the limitation of Post-Soviet balletic repertory, the ballerina connects the concept of technique or "Russian school of ballet" with the set of choreographic works, annually showcased by Bolshoi and Mariinsky theatres. This noticed limitation and fixity of the Post-Soviet repertory, mostly focused on re-staging of Imperial and Soviet-era ballets, connects in a way to Ulyana Lopatkina's perception of ballet technique as "restraining" and defining "strict frameworks." Echoing Susan Foster's notion of technique cultivating bodies through its training regimens, "Russian school of ballet," or technique, cultivates bodies specifically for classical reproductions. ${ }^{23}$ 
Reference to the notion of "school" is evident in other ballerinas' narratives. Mariinsky prima Diana Vishneva elaborates on technique as dominating the very experience of dancing. In the documentary film Vsegda v Dvizhenii [Always Moving], Vishneva states:

Well, yes, there is this pink tutu. However, I think very differently-I think through labor, through the way it should appear on stage - to effortlessly become that princess. I know what a fairy tale is, I know what a princess means, but when you are standing on hard, stiff pointe shoes, and there is this partner who has to hold you or do pirouettes with you or some other technical complexities, or when you just can't breathe and you are fainting, or when you don't see anything, however, you need to continue with the dance- that's the only princess experience I have from the "school bench" [the very beginning of my training at school.] $]^{24}$

Here, Vishneva defines ballet technique as being inextricably linked to pointe technique, labor, and physical exhaustion, delineating the "princess" experience. The dancer points to a linear connection between dance and work, technique and "school," and in that illustrates and complicates dance scholarship definitions of technique.

Vishneva's perspective on the embodiment of princess-like characters in Imperial or Soviet-era ballets, like Sleeping Beauty or Cinderella, highlights existing scholarly connections between dance, technique and virtuosity to labor. In "The Labors of Michael Jackson: Virtuosity, Deindustrialization, and Dancing Work," Judith Hamera argues that virtuoso performers, like primas, profoundly demonstrate these connections:

Dancing is work: a job, the product of labor. It is also allegorical ... This dual status makes dancers significant, if largely unrecognized, rhetorical actors in public imaginings of bodies and work. Bodies in motion offer visible potent templates for imagining ways work is produced and consumed. Virtuoso performers illuminate these dynamics with special intensity. ${ }^{25}$

In her narrative, Vishneva diverts attention from the romantic character of a princess to the labor of the dancer put into its embodiment. Echoing Hamera's connection between dance and work, the ballerina connects "technical complexities" and ways of thinking about them with "school" practice and, more specifically, with her education at the Vaganova Academy of Ballet in St. Petersburg.

\section{Technique as Archive}

In an interview with Russian writer and producer Andrei Maksimov, Vishneva theorized ballet technique, or "school," as a barrier that limits and at the same time offers 
access to ballet employment. Responding to Maksimov's question as to why Vishneva does ballet at all even despite chronic pain and tiredness, the ballerina replied:

It is for that life, that gives you an understanding that this is a real, actual life that you want to live... And, in general, after this school ["school of Russian ballet"], well, when I crossed the barrier of the school [graduated from Vaganova Ballet Academy], I realized that this world - obviously, it is not miraculous, but this world is for me. This world became my life, my essence, my artistic development. ${ }^{26}$

Thus, according to Vishneva, "school" is a basis and pre-condition for employment in the state theatres and "development" within the Post-Soviet state-sponsored ballet world. In Zakharova and Vishneva's narratives, referring to "school" becomes a way to reflect on the taught ballet technique, the state institutions that produce state artists (Bolshoi Ballet school and Vaganova Academy), and also on technique as a self-constructing practice.

In another interview with Sati Spivakova, Vishneva critiques offering leading roles in classical ballets to younger artists and states that "'tekhnika [technique ]' is presented and taught not just by itself; it is of utter importance to feel this arabesque or the line that you have to 'sing.' It [technique] cannot come right away, during the first years [of working as a ballet artist]." 27 Vishneva implies that practicing, studying and performing ballet technique leads to the development of empathy with embodied characters and the aesthetics that dancers produce on stage. This view of technique as a container for empathy illuminates dance studies scholar Alexandra Carter's argument that there is a kinesthetic element specific to a dancer's perception of ballet and external to the audience's "gaze."28

Two other leading Russian ballerinas, Svetlana Zakharova and Mariya Aleksandrova, echo Vishneva's and Carter's emphasis on empathy. In an interview with Sati Spivakova, responding to the question of "What is more important in ballet-artistic interpretation of a character or technical elements?" Mariya Aleksandrova replied:

This is an excellent question, as it defines the main battle [in ballet]. I think that there is no theatre without soul [experienced emotions, shared with an audience]. Tekhnika [technique] should stay a means for expression. An audience should have a feeling that they can do it on their own, dance in the same way, and that it [technique] is [a] fairly simple and easy thing to do. Theatre without a soul, without pain, without despair and disenchantment does not have any purpose. ${ }^{29}$

Aleksadrova practically disavows the meaning of technique as a purpose in and of itself, stating that it should remain valued only as a "means for expression." Moreover, the prima argues that the audience should not pay special attention to technique, but instead focus on the ballerina's acting and interaction with her character and storyline. Besides, 
Aleksandrova insists on the audience's perception of ballet art as theatre and stresses ballet's potential to generate shared empathy with the characters and storyline.

The question of the relative significance of technique and ballet's "emotional part" circulates in multiple interviews, showcasing a larger debate that Post-Soviet ballet provokes. In one of the interviews, to the similar question "everyone knows that ballet training signifies physical exhaustion, what attention does the emotional part get?" Zakharova replied:

Everything depends on the teacher. Our ballet teachers regularly required us to read special books on ballet, watch films, attend museums and theatres... Also, our teachers often brought thick books with copies of various famous drawings and works of world-known artists. As I lived in the ballet boarding school [attached to Vaganova Ballet school], our teachers had to be responsible for our [ballet students'"] upbringing. ${ }^{30}$

Zakharova, as Vishneva, refers to the school and her teachers, when considering the imagined contradiction between technique and the "emotional part," stating that, in fact, the former comes with the latter. Zakharova points the very process of technique study as long-term training, structured by the ballet school's schedules and ballet teachers' concerns, to further argue against the imagined opposition between technique and the "emotional part." Furthermore, both Vishneva and Zakharova point to the fact that, while studying and living in the ballet boarding schools of Bolshoi Ballet school and Vaganova Ballet Academy, ballet technique comes alongside a broader education derived from academic study, personal conversations and cultural experiences. According to the primas, state ballet schools not only educate and produce state ballet artists but also construct a recognizable Russian ballet body, as a "body-of-ideas," to borrow Susan Foster's term. ${ }^{31}$

In the context of Post-Soviet Russian ballet, the notions of "school" or "tekhnika" illuminate broader arguments about technique being a constrictive regimen that cultivates particular body through a set of restrictions, and technique, functioning like language and as a means of expression. However, these opposing notions come together in the highly used concept of "school" or "Russian school of ballet," highlighting the institutional element of acquired technique. It is precisely the "school" that on one hand serves as gates to the ballet "world" and self-development, and on the other, the "strict frameworks" of classicism and dancing the same productions year after year. As Judith Hamera writes, "it [dance technique] is both taskmaster and mastered, both warden and liberator." ${ }^{32}$ However, 
for Post-Soviet artists, it is particularly the "school" or "Russian school of ballet" as an institution, which becomes technique.

In the documentary Vsegda V Dvizhenii [Always Moving] Diana Visneva stated that "naturally, classicism is already under the skin, you will never forget it," echoing Susan Foster's statement that "with repetition, the images used to describe the body and its actions become the body." 33 Location of classicism or technique inside a ballerina's body is overly present within the ballet public discourse. In the interview with Maria Aleksandrova, one of Sati Spivakova's questions fixes the ballerina's body as a body of classicism: "Maria, you are an absolutely typical representative of classical ballet, you are a classical ballerina "do mozga kostei [to the bone] right?"34 Even though in her response the ballerina clarified that she started with "contemporary choreography" and dancing Boris Eifman's works, the very positing of the question points to the fact that it is not only ballerinas, like Diana Vishneva, who locate classicism inside their bodies, but also that Russian cultural actors, TV hosts and art journalists, like Sati Spivakova, do so.

This theorization of Post-Soviet ballerinas as bearers or containers of classicism (or classical ballet technique) relates to the prominent framework of body as an archive. In Performing Remains: Art and War in Times of Theatrical Enactment, Rebecca Schneider coins the term body as an archive; Schneider argues that through continuous repetition and re-enactment, the body becomes a material holder of collective memories and historic practices. ${ }^{35}$ Starting with Lopatkina's narrative of historical ballet trick 32 fouettes as the only focus of audience's attention, and continuing with public framings of Post-Soviet ballerinas as "classical to the bone" both ballerinas and various cultural actors locate technique as an archive in ballet bodies. It seems that ballet schools, long-time affiliated with state ballet theatres of Bolshoi and Mariinsky, function not just as schools and boarding schools, but also as relatively closed state entities with their own educational programs, artistic degrees, libraries, and archives. Ballet bodies, produced within these schools and consequently showcased in these theatres, continue and carry ballet technique as an archive through their performances and narratives. However, it is not only technique that turns ballerinas to bodies as archives, but choreography as well. 


\section{"Texts" and "Editions": Choreography as Archive}

The notion of technique or "school" is directly associated with ballet productions or "editions" and seems to be dominated by them. For example, in one of her interviews, Svetlana Zakharova highlights the notion of "editions" in reference to classical ballets. Through the phrase "I danced eight to ten editions of each ballet," the ballerina highlights Post-Soviet ballet works as archives and presents them as consecutive, similar and authorless productions. The ballerina's very urge "to change something" (in the repertory) constructs ballets "editions" as repetitive archival versions of one another. Notably, while ballets' choreographers are always mentioned before and during the seasons in public media, ballerinas rarely reference choreographers, depersonalizing and framing productions as "editions" or "texts." Given that the first cannot become the latter in the context of post-Soviet Russian ballet-Russian ballet choreographers are traditionally male ballet artists - this is a rather bold statement.

In one of her interviews, Vishneva also refers to classical ballets as editions, and connects it, like Zakharova, to the state:

When I saw the Western editions of The Swam Lake made in the West, I have realized that they are closer to me. First, we have a positive ending [here, in Russia], which cannot be true if to take into consideration Tchaikovsky's music. Second, The Black Swan character is significantly more developed in the Western editions. So, for me, it was more interesting and pleasurable to find my own swan there [at the West, outside of Russia]. ${ }^{36}$

Thus, the highlighted archival feature of classical ballet, along with its connection to the state and general avoidance of attributing authorship, relates to Taylor's argument on the political power of the archive. According to Vishneva, Russian editions of The Swan Lake are relatively similar with the only particularity in its difference from the generalized Western editions. It seems that constructing ballets as editions and, hence, as archives, dancers attempt to remind their audiences about the presence of state mediation, censorship, and power hierarchy within the spaces and practices of state ballet theatres. In the same interview, Zakharova mentioned, "Bolshoi Theatre is a state within a state," echoing Mariya Aleksandrova, stating, "Theatre is constructed on the basis of a pyramid principle." 37

The ballerinas' views resonate with scholarship on dance as a political power. In "Between Technique and the State: The Univers(ity) in Dance," Martin states, "Dance 
technique can be considered a political practice precisely to the extent that it represents a moment where bodies that are primitive with respect to their subordination to a given authority develop the means to move for and against that very authority." 38 In the interviews with Russian primas, however, the question of authority is eliminated, as if the classical ballets that define the very structure of technique and training regimens reproduce themselves. It is particularly through this invisibility of Russian choreographers, ballerinas "move against the authority," misrecognizing the work of state-hired choreographers. However, through framing productions as archival documents-“editions" or "texts"ballerinas reverse existing domination of archival ballet productions over the Post-Soviet repertory and reassign the agency to themselves by making these "texts" alive. In one of her interviews, Lopatkina states:

There are higher expectations for leading dancers; we have to make the material live, light and ephemeral. At the same time there has to be a drawing; a drawing from the front, back, above, and diagonally. And also, someone is always watching from behind the curtains. You have to create a drawing, and at the same time execute it as dance. These movements have to become dance; you have to interpret them. As our teachers tell us - "Sing that to me, I have to feel it." 39

Here, choreography is further defined as a drawing, having multiple perspectives; it is not just two-dimensional, but rather five-dimensional, as the phrase "someone is always watching from behind the curtains" further abstracts the choreographer and choreographic power.

Lopatkina's definition of choreography as a "material" and "drawing" clearly correlates to Lepecki's connection of choreography to a mechanism of power. The opposition between choreography as fixed "material" and dance, as live and ephemeral, demonstrates Lepecki's argument about choreography as an oppressive structure, casting dance as ephemeral and disappearing. ${ }^{40}$ However, at the same time, this framing of dance as ephemeral opens a window for resistance and interpretation, giving hope for the construction of self and subjectivity. According to Sally Banes, ballet dancers have various options in terms of interpretation of choreography and adding their own accents through bodily movements. In that, Banes resonates with Lopatkina and her view that the dancers' role is to bring choreography as a "material" back to life, "interpret" and open it as a platform for feelings. Through the notion of dance as interpretation, ballerinas reassign the role of writers and creators to themselves, while leaving official choreographers with "editions" and "materials" — fixed objects of the archive. 


\section{(Re)Locating Choreography}

While notions of choreography and technique do not seem to be prevalent within ballet discourses of Russian primas, they still dictate, to an extent, the dancers' very lives. In all the interviews examined in this study, ballerinas talk about their self-initiated work with European or American choreographers. In one of her interviews, Diana Vishneva considers various pieces staged specifically for her, namely Paul Lightfoot's The Object of Changes, Nacho Duato's Versatility. Forms of Silence and Emptiness, and John Neumeier's Dialogues. Unlike her characterization of Russian choreography as “editions," Vishneva characterizes the above authors as "choreographers" and locates her potential for self-realization in working with them on modern or contemporary dance productions. Vishneva articulates, "I am dreaming about working with a choreographer, because this is the only way to find one's individuality (...) I am well aware of my limit, of the time of my artistic span, this is why I aspire to work with them so much. It is an opportunity for me to have a fresh start, to open up, and start with a new clean slate." ${ }^{41}$ In all, Vishneva mentions ten other productions, created for her by foreign "choreographers." Zakharova echoes Vishneva, stating that "I wouldn't like to repeat something [classical ballets] that has been performed a million times; I want to feel myself in something new, something that no one has seen me before." 42

It seems that for Post-Soviet primas, "choreography" is located outside of Russia and outside of the state theatres and classical ballets. "Choreography" for Vishneva, and other Post-Soviet primas, signifies collaboration, "chemistry" and dialogue; it is something fresh, ahistorical, non-classical and existing in the moment, rather than in history. The narrative of a new beginning, of "starting with a clean slate" signifies dissatisfaction or discomfort with one's acquired identity. Given, Vishneva and Zakharova are current primas, stars, and symbols of Russian ballet, these narratives seem especially problematic, framing ballet as a practice that restricts subjectivity and eliminates the space of possibility.

\section{Conclusion}

In a 2012 interview, Ulyana Lopatkina, a contemporary Russian prima ballerina of Mariinsky Ballet, stated:

How does one express their emotions through a restrained, small-amplitude motion? It is incredibly hard to translate it through the ends of one's fingers. How 
does the audience feel the flow, coming from the music? There are no words; gestures are captured by certain frameworks. How? One can't rip their soul apart. Everything is very strictly defined. Seriously, how? Sometimes you have tears own your cheeks [during the performance], you are feeling something [for the character]. Then, a spectator comes [backstage] and says - it was all right, good job. Fouettes were nicely done. ${ }^{43}$

In her assessment, the ballerina points to the increased empathy for the character and its divergence with the primary significance of virtuosity, exemplified through the performance of fouettes. I argue that Lopatkina's allusion to "certain frameworks" that strictly define "everything" refers specifically to choreography and dance technique of classical ballets. It is in this domination of strict frameworks, constructed partially through the written documents (such as music scores, librettos, critical reviews, artistic sketches, photos, and videos), ballet's archival power reveals itself. Due to heavy reliance on the Soviet and Russian Imperial ballets across state-sponsored ballet companies of Post-Soviet Russia, ballet archive subjugates the repertoire through the requirements of reproduction of virtuosic technique and historic choreography. ${ }^{44}$

Available interviews with Post-Soviet primas provide a unique platform for their audiences and dance scholars to imagine and examine narratives and debates central to the Russian ballet. While reviews of ballets trace solely performance on stage, virtuosity and acting talent, this work attempts to shed light on the ways ballet artists perceive their work and its possible effect. I show that through the notions "school," "classicism," and "frames," contemporary Russian ballerinas refer to dance technique, as inexplicably connected to the education at the ballet schools and affiliated with the state theatres. This positioning of technique as school relates to the audiences' and theatres' construction of ballet artists as archives, and in that as carriers of pure classicism, transmitted in the very spaces of theatres and affiliated schools. In this capacity, ballet technique of contemporary Russian primas becomes connected to the preceding Soviet and Imperial primas and their virtuosity and is seen as a natural continuation of an established cultural institution.

According to Judith Hamera, bodies may come and go, but technique remains, referring to the historical translatability and transmission of technique from one choreographer to choreographer, from dancer to dancer. ${ }^{45}$ The located classicism inside ballerinas' bodies, evident in the dancers' and critics' narratives points to the overarching understanding of technique as an archive. However, as I have shown, choreography can also become the archive, in that ballerinas directly underscore subsequent classical 
productions as "editions," "texts," and "drawings," but not as independent choreographic works. These dancer-theorized frameworks disrupt scholarly narratives of dance as a purely embodied practice, located in the repertoire, and point to archival elements of such genres as ballet.

The concept of choreography, as existing in a space outside of the state theatres and of the country itself becomes central and even more significant in the light of classical ballets being framed as archives by the dancers. It seems that Russian primas employ two tactics of resisting the archival nature of the Post-Soviet ballet art, through either engaging with the character and creating a greater empathy for the performance or initiating collaborative work with foreign choreographers. Interestingly, both of these methods or tactics aim at realizing creative potential outside of current Russian ballet productions. As Vishneva noted: "everyone tells me they want to see me in Don-Quixote. Well, I don't want to see myself in Don-Quixote." 46

Finally, for Russian primas, choreography seems to be closely related to the concept of self, where one is the method and a necessary element for another. This view drastically contradicts some of the leading frameworks in dance scholarship, for example, Lepecki's notion of choreography as tyranny, fixing and eliminating dance in itself. ${ }^{47}$ Yet for Russian primas, there appears to be no self without choreography, and there is no choreography without the self. Some primas, like Lopatkina, attempt to find the self in engaging with the character and creating gesture through very subtle movements, resonating with Sally Banes's argument of existing possibility for choreography's interpretation. Others, like Vishneva, see the only possibility of self-definition in working with international choreographers and find it in the very different frameworks of modern and contemporary dance. It appears that for many leading Russian ballet artists, choreographies of state theatres exist only as archives, without a pathway of self-expression. Finding oneself requires escape; either by charting and experiencing new emotional connections to ballets' central characters or escaping beyond the national ballet stage altogether.

\section{Endnotes}

${ }^{1}$ Officially, the title and rank of a prima ballerina has been retired by all Russian state companies, in favor of the general title of ballerina [principal dancer]. However, the term prima remains ubiquitous across popular and academic discourses, when referring to the leading female ballet artists, who take on an additional role of ballet's 
public representatives. I use the term prima throughout the article to refer to this discourse and signify the role of leading ballerinas as important actors in the postSoviet cultural space.

${ }^{2}$ All translations of ballet artists' quotations are mine.

${ }^{3}$ More specifically, primas use the notions of "shkola [school]," "klassika[classicism]" and "ramki[frames]" to refer to the concept of dance technique.

4 In particular, primas use the notions of "tekst[text]," "redakciya[edition]" and "risunok[drawing]" to refer to ballet choreographies.

${ }^{5}$ Diana Taylor, The Archive and Repertoire: Performing Cultural Memory in the Americas (Durham and London: Duke University Press, 2003), 18.

6 These notions are evident in interviews with Bolshoi Ballet's primas Mariya Aleksandrova and Svetlana Zakharova and Mariinsky Ballet's primas Diana Vishneva and Ulyana Lopatkina.

${ }^{7}$ Christina Ezrahi examines the works by Leonid Yakobson and Yurii Grigorovich in the chapters "Enfant Terrible: Leonid Yakobson and The Bedbug, 1962" and "Choreography as Resistance: Yuri Grigorovich's Spartacus, 1968," respectively. Janice Ross dedicates Like a Bomb going Off to the works of Leonid Yakobson.

${ }^{8}$ For more information, see Simon Morrison, Confidential: Secrets of the Russian Ballet From the Rule of the Tsars to Today (New York: W.W. Norton \& Company, 2016). Simon Morrison perpetuates Ezrahi's and Ross's focus on the high politics of ballet, and in his chapter "I, Maya Plisetskaya" couples examination of the ballerina's biography with two accounts: an autobiography by Bolshoi Theatre's former director Mikhail Chulaki and Our Motherland by journalist George Feifer. Morrison's brief summary of Plisetskaya's autobiography through the prisms of male cultural actors, like Mikhail Chulaki and George Feifer, only extends the framing of ballerinas' narratives and bodies as secondary in ballet internal hierarch and its relationship to political power structures.

${ }^{9}$ Mariya Aleksandrova, Interview by Sati Spivakova, Neskuchnaya Klassika [Exciting Classicism], YouTube, February 21, 2017. https://www.youtube.com/watch?v=_a9a27FFZYw

${ }^{10}$ Harmony bench and Kate Elswit, "Mapping Movement on the Move: Dance Touring and Digital Methods," Theatre Journal 68, no 4, (2016): 576.

${ }^{11}$ Susan Foster, "Dancing Bodies," in Meaning in Motion, ed. Jane C. Desmond (Durham, NC: Duke University Press, 1997), 237-256, 238.

12 Randy Martin, "Between Technique and the State: The Univers(ity) in Dance," in Critical Moves: Dance Studies in Theory and Politics (Durham and London: Duke University Press, 1998).

13 Judith Hamera, Dancing Communities: Performance, Difference and Connection in the Global City (New York: Palgrave Macmillan, 2011), 5.

${ }^{14}$ Claudia Brazzale, "(Un)covering ground: dance, space and mobility," Theatre, Dance and Performance Training 5, no 2, (2014): 112.

${ }^{15}$ Foster, 238. 
${ }^{16}$ Martin.

${ }^{17}$ Foster, 239.

${ }^{18}$ Hamera, 5.

${ }^{19}$ Brazzale, 112.

${ }^{20}$ Both of these academies trace their histories back to the imperial times, while all other Russian ballet schools were established during the Soviet period and were stuffed by the graduates of either Vaganova or Bolshoi Ballet academies.

${ }^{21}$ Svetlana Zakharova, Prima-Balerina Bolshogo Teatra Svetlana Zakharova. Otkrovenie [Bolshoi Ballet's Prima-Ballerina Svetlana Zakharova. Revelation], Documentary Film, Katie Kharaidze (2014; Moscow: Art Capital Film, 2014), translation mine.

${ }^{22}$ Here, I use the term "repertory" to refer to the set of choreographic works, regularly exhibited by Bolshoi and Mariinsky theatres, and to avoid an association with Diana Taylor's repertoire.

${ }^{23}$ Ulyana Lopatkina. Interview by Natalya Gorodetskaya, Sekrety Uspekha [Secrets of Success]. YouTube, October 9, 2012. Translations of all Ulyana Lopatkina's quotations are mine. https://www.youtube.com/watch?v=1cCyNHzuWMg

24 Diana Vishneva, Vsegda v Dvizhenii [Always Moving], Documentary Film, Nika Strizhak, (2012: TV Channel Rossiya-Kultura[Russia-Culture], TV Company Naobum [At Random]), YouTube, December 10, 2012. https://www.youtube.com/watch?v=ZqsO0EN7UIo

${ }^{25}$ Judith Hamera, "The Labors of Michael Jackson: Virtuosity, Deindustrialization, and Dancing Work" PMLA 127, no 4, (2012): 752.

${ }^{26}$ Diana Vishneva, Interview with Andrei Maksimov, Lichnye Veshi [Private Things], Pyatyi Kanal Rissya [Fifth Chanel Russia], August 9, 2017. YouTube. https://www.youtube.com/watch?v=eLAyb40d43g

27 Diana Vishneva, Interview with Sati Spivakova, Neskuchnaya Klassika [Exciting Classicism], YouTube, February 6, 2012. https://www.youtube.com/watch?v=WNLhPWL1_H0

${ }^{28}$ For a detailed discussion of empathy, see Alexandra Carter, "Dying Swans or Sitiing Ducks?: A Critical reflection on Feminist Gazes at Ballet," Performance Research 4, no 3, (1999): 91-98. In her work, Carter considers kinesthetic experience to offer a critique of feminist approach in Ballet Studies, that, according to the author, focus solely on the male audience's perception of ballet works.

29 Aleksandrova.

30 Svetlana Zakharova, Interview with Marina Starostina, Ekskliuzivnoe Interview [An Exclusive Interview], RDT na Russkom [RDT in Russian], YouTube, March 21, 2016. https://www.youtube.com/watch?v=MDo9fSwhycs

${ }^{31}$ Foster, 239.

32 Hamera, Dancing Communities, 4.

${ }^{33}$ Vishneva, Diana. Vsegda v Dvizhenii [Always Moving]; Foster, 239. 
${ }^{34}$ Aleksandrova, Mariya. Interview with Sati Spivakova, Neskuchnaya Klassika [Exciting Classicism]. In Russian, the medical term for bone marrow is "kostnyi mozg," which translates as "bone brain," becoming a common metaphor for embodied memory, to use Taylor's term.

35 Rebecca Schneider, Performing Remains: Art and War in Times of Theatrical Reenactment (New York: Routledge, 2011), 102.

${ }^{36}$ Vishneva, Interview with Sati Spivakova.

37 Zakharova; Aleksandrova..

${ }^{38}$ Randy Martin, 156.

${ }^{39}$ Lopatkina.

${ }^{40}$ For a discussion of the concept of choreography and its oppressive character, see Andre Lepecki, "Choreography as Apparatus of capture," TDR: The Drama Review 5, no 2, (2007), 119-123.

${ }^{41}$ Vishneva, Vsegda v Dvizhenii [Always Moving].

42 Zakharova.

${ }^{43}$ Lopatkina.

${ }^{44}$ Interestingly, both Christina Ezrahi and Simon Morrison attribute particular significance to the Soviet period that allowed a continuation of pre-existing ballet state sponsorship and incorporation of Russian Imperial ballet works in Soviet repertory. Ezrahi legitimizes the major focus of Swans of the Kremlin on the 1950s and 1960s as, according to the author, these decades came to symbolize "the golden age" of Soviet ballet. Morrison echoes Ezrahi's prioritization of the Soviet ballet and argues that the Soviet period still haunts Russian theatres.

${ }^{45}$ Hamera, Dancing Communities, 8.

46 Vishneva, Diana. Vsegda v Dvizhenii [Always Moving].

${ }^{47}$ Andre Lepecki, 122. 